\title{
O VISIONÁRIO DA TANGIBILIDADE
}

\author{
Helder Macedo*
}

José Saramago tinha o dom da generosidade. Creio que sempre deu mais do que recebeu. E o que recebia, partilhava. Há escritores que se afirmam criando um vácuo à sua volta, que interiorizam o mundo como uma paisagem da alma. Saramago falava a partir de si para o mundo, forjava o que seria a imagem da sua alma na paisagem transitória de mundos possíveis. Sabia que só a morte é imortal. Era um materialista visionário, um místico da tangibilidade.

O estilo literário que desenvolveu - que encontrou na sua primeira grande obra, Levantado do Chão - faz uma sábia fusão de didatismo e de subversão, que lhe permite levar o leitor para mais longe do que, só por si, teria julgado ser possível. É como se o autor pegasse no leitor pela mão e o levasse, de pormenor em pormenor, a encontrar respostas plausíveis para perguntas que não tinha feito, e assim chegar a uma conclusão para que não teria estado preparado, mas a que chega como se tivesse seguido um percurso independente. Sendo eu um escritor que funciona através de elipses e de cesuras, de justaposições e de silêncios intervalares que visam a criar espaços vazios que o leitor poderá (ou não) preencher consoante o seu próprio entendimento, profundamente admiro essa capacidade oposta de nada deixar ao acaso, de tudo prever, de tudo fazer o leitor ver e pensar, de conseguir que nada pareça aleatório, mesmo o que parta, como em várias das sua obras, de uma proposição ela própria aleatória: e se o Ricardo Reis que não houve voltasse à Lisboa que havia? E se a Península Ibérica se separasse, como uma jangada de pedra, do continente europeu? E se de repente todos ficassem cegos? E se deixasse de haver morte? Saramago transpôs o surrealismo que fora dominante nos anos formativos da sua geração literária na lógica rigorosa de uma literatura aparentemente realista.

Coincidimos várias vezes em encontros literários, sobretudo no Brasil. Sempre senti, e julgo ter sido um sentimento partilhado, que havia entre nós uma base de cúmplice amizade que só a distância geográfica - ele em Portugal ou em Lanzarote, eu em Londres - não permitiu que fosse aprofundada. Mandava-me os seus livros, eu mandava-lhe os meus, fiquei sempre a beneficiar com a troca. Foi por recomendação sua que um romance meu, Pedro e Paula, foi traduzido e publicado

"Escritor-poeta, ficcionista e ensaísta, professor catedrático emérito da Universidade de Londres, King's College, onde foi Camoens professor de 1982 a 2004. 
na Itália. Já doente, há poucos meses, escreveu-me palavras apreciativas sobre o meu último romance. Ele tem milhões de leitores, eu, poucos milhares. Sinto-me honrado por José Saramago ter sido um deles, por esse escritor generoso ter sido também um colega generoso. Generoso para mim e para muitos outros. O prémio literário que criou com o seu nome é uma aposta nos escritores de um futuro que já não poderá partilhar. Quando alcançou um reconhecimento internacional que nenhum outro escritor português alguma vez teve, abriu portas a todos os escritores portugueses. Até a Camões, até a Pessoa, até mesmo àqueles que se promovem pela negativa às cavalitas nele, como aconteceu quando um colega menos generoso foi lançado no Brasil como o «Anti-Saramago».

Foi também no Brasil que, depois de uma breve apresentação do Evangelho Segundo Jesus Cristo, ouvi o José Saramago responder a perguntas do público durante mais de duas horas. Anfiteatro cheio, gente quase literalmente pendurada dos candeeiros. Isto bem antes do Nobel, não foi o Nobel que levou ao sucesso da sua obra, foi a sua obra que levou ao Nobel. Um monte de papelinhos com as perguntas sobre a mesa, o José Saramago devotando a todas elas a mesma atenção, tratando as mais banais com o mesmo respeito que devotava às mais complexas, sem a menor sombra de impaciência, didático, inteligente, sedutor, nunca comprometendo a sua integridade intelectual. Aplausos entusiásticos a cada resposta. Exemplo: «O senhor acredita na reencarnação?» Eu a tentar imaginar como me teria saído dessa, como traduziria numa linguagem minimamente cordata o «é claro que não, que parvoíce» que me teria apetecido responder. Mas logo percebi por que razão ele conseguia ser simultaneamente o escritor que eu admirava e o comunicador que fiquei a admirar. Releu a pergunta, ponderou uns segundos, «Bom, vamos lá ver», e respondeu longamente com uma análise das mais diversas crenças na reencarnação através dos séculos, mostrando que todas elas tinham um elemento comum: a pessoa não se lembrar de quem teria sido numa vida anterior. E assim pôde concluir, com os aplausos de todos nós: «Portanto, está a ver, sendo assim é um problema que não me ponho.» Sabia muito. Até sabia como manipular o sentimentalismo com a verdade dos sentimentos. A senhora da reencarnação insistiu em fazer uma última pergunta, todos nós já merecedores de um copo sem metafísica: «Saramago, por que é que Jesus, quando ressuscitou, foi ver Maria Madalena e mais ninguém?» Resposta rápida, olhando nos olhos a bela Pilar sentada na primeira fila: «Mas, como não?, se eu ressuscitasse a pessoa que eu iria ver é a mulher que amo». Pois é, o José Saramago sabia muito. 